\title{
Skill Premium and Technological Change
}

Harshil Sharma

PhD Scholar, Centre for Informal Sector and Labour Studies, School of Social Science, Jawaharlal Nehru University, New Mehrauli Road, New Delhi - 110067, India; harshilsharma0907@gmail.com

\begin{abstract}
The paper tests the presence of skill premium and capital skill complementarity in the Indian Economy. Using NSSO data for skilled and unskilled workers measured on the basis of educational qualification, the study attempts to find factors that affect the movement in skill premium in the Indian labour market. Using two different definitions, the study finds that skill premium does not show a stagnant behaviour. This was due to factors specific to the Indian economy- a large reserve army of labourers and a weak relative absorptive capacity of different sectors. Firms prefer adopting techniques such as flexibility, outsourcing, de-unionisation and hiring contract workers for maintaining higher level of profits rather than adopting new technologies. On account of these factors, Skill Biased Technical Change (SBTC) and acceleration hypothesis could not be observed in the Indian Economy.
\end{abstract}

Keywords: Capital Skill Complementarity, Indian Economy, Skill, Skill Premium, Unskilled Workers, SBTC JEL classification: J240, J60, I26, J62, L60, 033

\section{Introduction}

Skills and knowledge are twin forces which help in economic growth and social development of individuals and a country. Countries which possess large pool of skilled labourers have a higher tendency to adjust to challenges and opportunities that are posed by the world of work. When a country wants to achieve twin targets of economic growth and inclusive development, it becomes necessary that wage gap between skilled and unskilled workers is kept under check.

Skill is broadly defined as a learned ability of an individual to carry out a set of pre-determined tasks ${ }^{1}$. 'Skill' means any marketable expertise, however acquired, irrespective of whether marketed or not, or whether the intention is to market it or not ${ }^{2}$. Skill Premium in simple words means the relatively higher wages received by skilled workers as compared to the unskilled workers. The relative wage gap between the skilled and unskilled workers gives the motivation to unskilled workers to acquire skill. The focus of this study is to explain changes and movement of Skill Premium, drawing the reasoning from how skill requirements are treated by the labour force.

Skill Premium is defined as ratio of wages received by skilled workers compared to that of received by the unskilled workers. The definition of skilled and unskilled workers varies from author to author. Over a period of time different studies have used different definitions in the context of skill premium. Few studies have categorised 'blue collar workers' as unskilled and 'white collar workers' as skilled 3 . Some studies have defined production workers as unskilled and non-production workers as skilled $\frac{16,31}{16}$.

Skill can be treated as a social category, which has both political and ideological determinants and consequences. When a study takes educational attainment as proxy of skill then it may not be an adequate representation of skills as it does not look at skill through a holistic angle but the opportunity cost of choosing any other definition, is quite high and the best available alternative is to see educational attainment. In a country like India, educational attainment as a proxy of skill premium is even more difficult to assess, as there is a large section of population in India who have not attained high levels of education but through years of experience they have learned techniques to carry out the most complex and skilful tasks ${ }^{22}$.

There is a wide literature available on definition of skilled and unskilled labour but this study specifically considers educational qualification as proxy of skills ${ }^{19}$. Now in case of narrowing definition of skill to education, there 
are more distinctions among authors, some take secondary education attained workers as skilled and others (less than secondary education) as unskilled ${ }^{4,20}$ and few take graduates as skilled and others (under graduates) as unskilled ${ }^{5,25,33}$. An appropriate way of distinguishing would be to categorise graduate labourers as 'skilled', labourers with secondary education as 'medium' skilled and others as 'unskilled' However, with such classification, two problems arise. Firstly, defining skill premium becomes difficult as skill premium is a ratio among two variables. Secondly, incorporating labour with diploma and certificate courses, who according to NSSO should be considered as 'skilled', also becomes complicated. To have more accurate results the skilled labour demand and supply data with reference to their occupations, is needed for which National Skill Development Corporation (NSDC) has started collecting state-wise and sector-wise data but due to limitation of wage data not being available the current study is using the NSSO data.

Table 1. Definitions: Skill Premium

\begin{tabular}{|c|c|c|}
\hline Premium & Skilled Worker & Unskilled Worker \\
\hline Skill Premium 1 & $\begin{array}{c}\text { Secondary } \\
\text { education and } \\
\text { above }\end{array}$ & $\begin{array}{c}\text { Less than } \\
\text { Secondary } \\
\text { education }\end{array}$ \\
\hline Skill Premium 2 & $\begin{array}{c}\text { Graduation and } \\
\text { above }\end{array}$ & $\begin{array}{c}\text { Less than } \\
\text { Graduation }\end{array}$ \\
\hline
\end{tabular}

Source: Author's own definitions.

The current Study considers two definitions of skill premium-Skill Premium 1 considers labour with secondary education and higher than secondary education levels as skilled labour. For the $64^{\text {th }}, 66^{\text {th }}$ and $68^{\text {th }}$ NSSO rounds, since data for diploma certificate/technical educations degrees is also available, we define Skill Premium 2 by considering labour with graduation and higher education levels as skilled and others as unskilled labourers.

The major reason for adoption of two skill premiums is that under skill premium 1, the methodology adopted is the same as used by other authors thereby facilitating easier comparisons. Also, this definition enables us to undertake a longer time framework, since data for skill premium 2 is only available from 2007 . However, premium 2 defines skill premium in a more comprehensive manner considering sections of society that acquire education to primarily secure a job. Also the effect of skill premium programmes can be incorporated in skill premium 2. Both the skill premiums will be analysed for comparison purposes and the more suitable definition of skill premium in case of the Indian economy will be discussed in the next section.

Table 2 shows years of education completed on average by different percentage of the Indian workforce. It highlights all the forms in which general and vocational education has been attained by the workforce of India. From the table we find that the state of education is very poor in India. Only around 68 percent of the Indian workforce had passed $8^{\text {th }}$ Standard in 2011-12. More specifically, 28 percent of the labour force was illiterate, 22 percent had studied up to the primary level and 17 percent up to the middle level. When elementary education, a preliminary requirement of the existing skill development system and programmes, has

Table 2. Percentage Share of Total Workforce in India at Various Education Levels in 2011-12

\begin{tabular}{|c|c|c|c|c|c|}
\hline $\begin{array}{c}\text { Average Years of } \\
\text { Education Completed }\end{array}$ & Grade & \multicolumn{4}{|c|}{ Qualification and Percentage of Workforce in 2011-12 } \\
\hline 18 & PG & Post graduate and above- 2.53 & & & \\
\hline 16 & UG & Graduate- 6.82 & & & \\
\hline 13 & 11th-12th & Senior Secondary- 6.14 & Polytechnic (3 years)- 0.48 & \multicolumn{2}{|c|}{ CTS and ATS $^{*}-2.26$} \\
\hline 11 & 9th-10th & General Secondary-12.26 & Vocational Secondary-0.02 & & \\
\hline 9 & 6 th-8th & Middle-17.48 & & & \\
\hline \multirow[t]{2}{*}{$0-6$} & 1 st -5 th & \multirow{2}{*}{ Up to Primary- 22.32} & & & \\
\hline & & & \multicolumn{2}{|c|}{ Literate without schooling- 0.47} & \\
\hline $\mathbf{0}$ & - & Not literate-28.73 & & & \\
\hline
\end{tabular}

Source: Computations based on Mehrotra (2014), IMA (2017), GOI (2013), AICTE(2012) and AISHE (2012).

${ }^{*}$ CTS- Craftsmen Training Scheme, ATS- Apprenticeship Training Scheme 
not been completed by majority of the workers, the failure of such programmes is inevitable. Only 0.02 percent of total workforce attend school level vocational education compared to 12.26 percent attending general education. Also at senior secondary level enrolment is 6.14 percent in general education and only 0.48 percent in polytechnics and 2.26 percent in CTS and ATS schemes which clearly indicate the worrying state of vocational education in India ${ }^{2 \underline{3}}$. According to NSSO estimation total workforce in India in 2011-12 was 370.2 million. In absolute numbers, the population with at least a graduation degree increased from 23.6 million in 2001 to 33.3 million in 2005 and further to 50.5 million in 2010, but wages received by educated employees is not rising at a similar pace. According to the current training capacity, around 5 million workers are trained per year but the requirement of skilled workforce is around 20 million workers ${ }^{6}$.

The current Study highlights and analyses the important issues of checking evidence of skill premium and technological change for the India economy. After an introduction, the second section presents the data sources used for the analysis. The third section analyses skill premium in case of Indian Economy. The fourth section checks the relation of technological change and evidence of SBTC and Capital-Skill complementarity. In the Fifth section sectoral shares and relation of skill premium and worker movement in different sectors in India is examined. Sixth section explains the broad findings of the Study and is followed by the concluding section.

\section{Data Sources}

The major source of data for this Study is NSSO survey reports on 'Employment and Unemployment in India' for the years 1999-00, 2004-05, 2007-08, 2009-10 and 2011-12. NSSO data was used for calculation of wage earnings by industry and occupation groups, proportion of labourers by education categories and proportion of labourers receiving vocational training. Indian Labour Employment Report (ILER) $\frac{15}{5}$ was used for calculation of formal-informal sector relations, KLEMS (Capital, Labour, Energy, Manufacturing and Services) data provided by Reserve Bank of India (RBI) was used for calculation of total workers by their industry code for analysing productivity. Few variables were calculated with the help of Handbook of Statistics for Indian Economy (2015) published by Reserve Bank of India (RBI). NSSO and Census data were used for calculation of share of workers over different years in different sectors. For calculation of relation between wages and profits, Annual Survey of Industries (ASI) data was used ${ }^{18}$. Other than this proportion of skilled workforce data computation was done with help of Unni and Rani ${ }^{-}$which used the NSSO unit level data.

\section{Proportion of Skilled to Unskilled Workforce}

The analysis begins by finding out evidence of skill premium in each sector separately by using both the premium methods. Before looking at the wages of skilled and unskilled workers it would be wise to look at the proportion of skilled and unskilled workers under both the premium methods.

Table 3. Proportion of Skilled to Unskilled Workers using both Premium Definitions (2004-05 to 2011-12)

\begin{tabular}{|c|c|c|c|c|}
\hline & \multicolumn{4}{|c|}{$\begin{array}{c}\text { Proportion of Skilled to Unskilled } \\
\text { Workers }\end{array}$} \\
\hline & Skill Premium 1 & \multicolumn{2}{c|}{ Skill Premium 2 } \\
\hline Industry & 2004 & 2011 & 2004 & 2011 \\
\hline Agriculture & 0.11 & 0.16 & 0.05 & 0.08 \\
\hline Mining & 0.24 & 0.34 & 0.21 & 0.27 \\
\hline Manufacturing & 0.32 & 0.46 & 0.20 & 0.28 \\
\hline Electricity & 1.51 & 1.53 & 0.90 & 0.90 \\
\hline Construction & 0.14 & 0.47 & 0.08 & 0.21 \\
\hline Trade & 0.60 & 0.75 & 0.31 & 0.45 \\
\hline Hotels & 0.25 & 0.56 & 0.13 & 0.22 \\
\hline Transport & 0.49 & 0.65 & 0.27 & 0.30 \\
\hline Finance & 5.85 & 9.30 & 3.24 & 3.08 \\
\hline Real Estate & 2.79 & 2.68 & 2.22 & 2.51 \\
\hline Public & 2.16 & 2.14 & 1.25 & 1.18 \\
\hline Administration & & & & 3.45 \\
\hline Education & 7.06 & 6.04 & 3.92 & 2.97 \\
\hline Health & 2.64 & 3.50 & 2.13 & 0.15 \\
\hline Other Services & 0.29 & 0.16 & 0.17 & 0.19 \\
\hline Private & 0.08 & 0.25 & 0.03 & 0.14 \\
\hline All & 0.26 & 0.38 & 0.17 & \\
\hline
\end{tabular}

Source: Computations based on Unni and Rani (2008) Indian Labour Employment Report (2014) and Roy (2008) and 61st and 68th NSSO rounds. 
Under skill premium 1 there is a constant and steep rise for all industries with the exception of real estate, education and other services. All the other sectors have witnessed arise in proportion of skilled workers as compared to the unskilled workers. The rise is apparent in construction, trade, hotels, transport and finance sectors. The situation changes when the proportion of skilled to unskilled workers is calculated using skill premium 2 approach where overall trend indicates stagnancy and there is not much rise in the proportion of skilled workers used as compared to unskilled workers in production. In fact, considering all industries there appears to be a decline in proportion of skilled workers. In most of the sectors the trend is stagnant but it is worth noting that for the construction sector where the proportion of skilled to unskilled workers has risen. During this period the construction bubble was witnessed in the economy and it is not represented well in the skill premium value. Probable reason for the same may be that employment across sectors had gone up for skilled workers but in relative terms, the employment of unskilled workers would have been much more which did not result in much change in the premium value. Interesting to see is under this premium definition manufacturing sector sees a rise in proportion of skilled labour used as compared to unskilled labour which may have largely to do with informalisation of labour force from the organised to the unorganised sector. As the NSSO data just takes the organised sector into account which shows rise in skilled workers being hired in the economy. For Premium 1 in most of the sectors shows higher proportion of skilled workers being hired as compared to Premium 2 where most of the sectors show stagnancy with respect to proportion of skilled workers being hired.

In Table 4 we notice that for total male workforce in India there is tremendous rise in skill premium 1 for agriculture over the three periods and it is continuously rising. Premium is continuously falling for both the manufacturing sectors but the decline is not very sharp. It is falling and then again rising for mining and quarrying, electricity, gas and water and trade. Surprisingly, the most debatable sector of the reference period is construction, for which it is continuously falling and so is the case with private sector. Overall for total male workforce it shows a decline in wages.

For female workforce, agriculture shows a fall in the first period but the value doubles in the second period as compared to its value in 2009. There is a tremendous fall in case of mining and quarrying as well as for both the manufacturing sectors; however, the fall is much higher for manufacturing 1 . For electricity, gas and water it falls and then rises back to the initial position in 2007.

Table 4. Skill Premium 1 for Workers of Different Categories: Male, Female and Total Workforce Categories (2007-2011)

\begin{tabular}{|c|c|c|c|c|c|c|c|c|c|}
\hline & \multicolumn{3}{|c|}{ Total India Male } & \multicolumn{3}{c|}{ Total India Female } & \multicolumn{3}{c|}{ Total India } \\
\hline Industry* & 2007 & 2009 & 2011 & 2007 & 2009 & 2011 & 2007 & 2009 & 2011 \\
\hline $\begin{array}{c}\text { Agriculture (01-05) } \\
\begin{array}{c}\text { Mining and Quarrying } \\
\text { (10-14) }\end{array}\end{array}$ & 2.96 & 3.21 & 3.99 & 2.19 & 1.79 & 3.18 & 2.98 & 3.19 & 4.28 \\
\hline Manufacturing1 (15-22) & 2.71 & 2.25 & 2.05 & 3.47 & 2.8 & 1.83 & 2.82 & 2.45 & 2.09 \\
\hline Manufacturing2 (22-37) & 3.04 & 2.99 & 2.87 & 3.66 & 3.44 & 3.33 & 3.01 & 3.09 & 2.95 \\
\hline $\begin{array}{c}\text { Electricity, Gas and Water } \\
\text { (40-41) }\end{array}$ & 1.98 & 1.76 & 2.56 & 2.75 & 1.58 & 2.86 & 2.03 & 1.75 & 2.65 \\
\hline Construction (45) & 2.32 & 2.18 & 2.04 & 2.15 & 4.11 & 3.75 & 2.32 & 2.3 & 2.23 \\
\hline Trade (50-55) & 2.14 & 1.92 & 2.18 & 2.17 & 2.42 & 2.12 & 2.15 & 1.92 & 2.16 \\
\hline $\begin{array}{c}\text { Transport and storage } \\
\text { (60-64) }\end{array}$ & 2.57 & 2.66 & 2.69 & 2.29 & 2.06 & 2.43 & 2.18 & 2.64 & 2.66 \\
\hline Services (65-93) & 2.85 & 2.41 & 2.22 & 2.24 & 3.38 & 3.46 & 2.86 & 2.68 & 2.68 \\
\hline Private & 2.08 & 1.5 & 0.9 & 2.74 & 0.8 & 1.32 & 3.02 & 1.83 & 1.23 \\
\hline All & 2.77 & 2.69 & 2.6 & 3.42 & 3.46 & 3.07 & 2.91 & 2.87 & 2.78 \\
\hline
\end{tabular}

Source: Computations based on NSSO: Employment and Unemployment Situation in India, Various Years.

${ }^{*}$ NSSO 2-digit level data classifies industries into 11 categories according to National Industrial Classification (NIC) 
For construction sector there is rise in premium value in 2009 , it falls in the next period, but even after a fall in the second reference period, the value remains quite high. It rises for services and transport and storage but overall trend for total female workforce shows a decline in value of skill premium 1 from 2007 to 2011.

For total workforce, when both male and female workers are considered, in the agriculture sector, skill premium value appears to have grown drastically. There is fall in premium value for mining and quarrying and both the manufacturing sectors. Even after movements in both male and female workforce, overall premium in construction and services sector remains the same. There is overall rise in the electricity, gas and water; and transport and storage but these rises are apparent after witnessing a fall in the second reference period. Overall for the whole economy, skill premium 1 has shown a secular decline even after showing rises in many sectors but the whole amount is also dependent on the proportion of population employed in certain sectors and the base average earnings received in that sector.

In Table 5, analysing Skill Premium 2 value for total male workforce, it can be observed that skill premium value for almost all sectors is stagnant or marginally decreasing with the exception of agriculture where there is drastic rise from 1.39 to 2.49. For female workforce it can be observed that premium 2 rises and then falls drastically for agriculture.
There is also a major fall for mining and quarrying and manufacturing1. However, for manufacturing 2, it is relatively stable. The value falls for electricity, gas and water but recovers in the next period. The construction sector suffers a major fall from 2009-11. A continuous rise for transport and storage and services and also a marginal rise for trade is witnessed. Overall it can be seen that premium 2 rises from 2007 to 2009 for female workforce and falls from 2009-2011 across almost all the sectors. Stagnancy seen in male workforce isn't witnessed for their female counterparts. For total Indian workforce, almost similar trends are apparent. Premium 2 falls for agriculture and allied activities, manufacturing 1 and manufacturing 2 . For construction, value of premium 2 rises marginally in the first reference period and then it falls drastically. For mining and quarrying, it remains constant. Continuous fall for electricity, gas and water and transport and storage and services can be seen but the fall is not as large as in the case of premium 1. Overall trend for premium 2 is of stagnancy in skill premium for majority of the sectors even though proportion of skilled workers according to this definition as seen in Table 3 were seen rising.

\subsection{Comparison of Premium 1 and Premium 2}

One of the broad findings that can be observed in premium 1 over premium 2 is that under premium 1 there are wide movements across sectors over the relative

Table 5. Skill Premium 2 for Workers of Different Categories: Male, Female and Total Workforce Categories (2007-2011)

\begin{tabular}{|c|c|c|c|c|c|c|c|c|c|}
\hline \multirow[b]{2}{*}{ Industry } & \multicolumn{2}{|c|}{ Total India Male } & \multirow[b]{2}{*}{2011} & \multicolumn{2}{|c|}{ Total India Female } & \multirow[b]{2}{*}{2011} & \multicolumn{2}{|c|}{ Total India } & \multirow[b]{2}{*}{2011} \\
\hline & 2007 & 2009 & & 2007 & 2009 & & 2007 & 2009 & \\
\hline Agriculture (01-05) & 1.39 & 1.5 & 2.49 & 2.76 & 3.32 & 2.33 & 1.44 & 1.56 & 1.08 \\
\hline $\begin{array}{l}\text { Mining and Quarrying } \\
(10-14)\end{array}$ & 1.04 & 1.06 & 1.5 & 1.86 & 1.9 & 0.52 & 1.07 & 1.09 & 1.02 \\
\hline Manufacturing1 (15-22) & 1.67 & 1.76 & 1.27 & 2.26 & 1.49 & 1.38 & 1.76 & 1.85 & 1.06 \\
\hline Manufacturing2 (22-37) & 1.91 & 2.05 & 1.91 & 2.65 & 2.08 & 2.34 & 1.93 & 2.06 & 1.07 \\
\hline $\begin{array}{l}\text { Electricity, Gas and Water } \\
\qquad(40-41)\end{array}$ & 1.33 & 1.16 & 1.35 & 2.1 & 1.07 & 1.49 & 1.35 & 1.16 & 0.86 \\
\hline Construction (45) & 1.67 & 1.67 & 1.63 & 2.23 & 2.76 & 0.86 & 1.67 & 1.73 & 1.04 \\
\hline Trade (50-55) & 1.55 & 1.27 & 1.54 & 1.78 & 1.76 & 2.01 & 1.55 & 1.28 & 0.83 \\
\hline $\begin{array}{c}\text { Transport and storage } \\
(60-64)\end{array}$ & 1.67 & 1.76 & 1.75 & 1.57 & 1.96 & 2.25 & 1.67 & 1.76 & 1.05 \\
\hline Services (65-93) & 1.63 & 1.44 & 1.32 & 1.39 & 1.55 & 1.85 & 1.61 & 1.49 & 0.92 \\
\hline Private & 1.01 & 0.76 & 0.54 & 1.38 & 0.96 & 0.46 & 1.25 & 0.88 & 0.7 \\
\hline All & 1.69 & 1.68 & 1.62 & 2.04 & 2.09 & 1.99 & 1.73 & 1.73 & 1.76 \\
\hline
\end{tabular}

Source: Computation based on NSSO: Employment and Unemployment Situation in India, Various Years. 
values of skill premium but in premium 2 the values across most of the sectors do not change and are fairly stagnant. Share of workers moving between rural to urban areas and rise in the value of agriculture and fall in the value of manufacturing, indicate movement of skill premium between sectors rather than within sectors.

Another interesting finding is the upward movement of premium value for agriculture sectors in skill premium across both definitions is apparent (relatively more in case of premium 1) across both genders. The period under Study is that of the global food crisis and Indian agriculture also did not perform very well during that period. This raises a question that how much the skill premium value has to do with the demand supply conditions in the market. Another sector that makes us believe that demand supply conditions have less to do with the movement of skill premium, is the construction industry. Under construction, there was rise in skill premium value for (for both premiums) but for the entire labour force taken together premium 1 was stagnant, and surprisingly a fall is observed in case of premium 2 . This is during the period when manufacturing sector growth was construction driven and there was a high demand of skilled workers in the construction sector. However, those demand driven factors do not seem to have resulted in a secular rise in case of skill premium for construction industry. For most of the sectors there was not much relation among proportions of skilled workers and premium, as we observe the proportion of skilled workers rising in a few sectors did not transform into rise in skill premium of that sector. For the service sector industries (other than construction) it could be seen that skill premium 1 witnessed a rise and skill premium 2 witnessed stagnancy. Thus, though GDP contribution from services sector is on a continuous rise, however, this growth is not getting converted into rise in wages for the workers.

\section{Evidence of SBTC and Technological Skill Complementarities in the Indian Economy}

Regarding the technological change in the Indian Economy and its relation to skill premium, firstly, one should look at Total Factor Productivity (TFP) which is one of the most widely used methods for measuring the changes in technological advancements. Overall trend shows that rise in TFP for primary and service sectors and

Table 6. Percentage Change in NFCS/Labour and Percentage Change in the Share of Skilled Workers by Industry (1999-2011)

\begin{tabular}{|c|c|c|c|c|c|c|}
\hline & \multicolumn{2}{|c|}{ \% Change in K/L } & \multicolumn{3}{c|}{ \% Change in the Share of Skilled Workers } \\
\hline & $1999-2004$ & $2004-2011$ & \multicolumn{2}{c|}{$1999-2004$} & \multicolumn{2}{c|}{ 2004-2011 } \\
\hline Industry & & & $\begin{array}{c}\text { Under } \\
\text { Premium 1 } \\
\text { Approach }\end{array}$ & $\begin{array}{c}\text { Under } \\
\text { Premium 2 } \\
\text { Approach }\end{array}$ & $\begin{array}{c}\text { Under } \\
\text { Premium 1 } \\
\text { Approach }\end{array}$ & $\begin{array}{c}\text { Under } \\
\text { Premium2 } \\
\text { Approach }\end{array}$ \\
\hline Agriculture, Forestry \& Fishing & 18.271 & 19.328 & 1.61 & 1.21 & 1.82 & 1.12 \\
\hline Mining \& Quarrying & 0.867 & -2.751 & 0.16 & .45 & .62 & .51 \\
\hline Manufacturing & 15.46 & 11.69 & -0.25 & -.67 & .13 & -.88 \\
\hline Electricity, Gas \& Water Supply & 18.908 & 62.62 & 0.03 & .12 & -1.02 & .2 \\
\hline Construction & 45.987 & 58.132 & 0.24 & 0.01 & .17 & -.02 \\
\hline Trade, Hotels \& Restaurants & -9.865 & 2.681 & 0.01 & 1.25 & 1.35 & 1.26 \\
\hline $\begin{array}{c}\text { Transport, Storage \& } \\
\text { Communication }\end{array}$ & 8.43 & 13.84 & -0.09 & .17 & .67 & .18 \\
\hline Financing, Insurance, Real Estate & 25.987 & 29.294 & -0.82 & .43 & -.21 & .305 \\
\hline Community, Social \& Personal & 21.76 & 11.283 & -.73 & -.56 & .16 & .482 \\
\hline Services & & & & & & .64 \\
\hline Total (1 to 9): Net Capital Stock & 27.229 & 21.374 & 0.03 & 0.23 & .64 \\
\hline
\end{tabular}

Source: National Accounts Statistics, Various Years; Employment and Unemployment Situation in India, Various rounds, KLEMS database (2014), CSO(2007) and Unni and Rani (2008). 
a fall or near stagnancy in the secondary sector. In the latter case, technology is considered as the major reason behind its growth and it is claimed that in the Indian manufacturing sector, skill premium is majorly driven by technological advancements in manufacturing sector. This however needs to be ascertained (KLEMS, 2014).

Total factor productivity is an indicator to look at the technological advancements. Direct contribution of technology to skill premium of workers can also be studied with the help of capital-skill complementarity.

For this, we look at the percentage change of capital labour ratio denoted by percentage change in Net Fixed Capital Stock (NFCS) divided by total labourers (K/L) employed. Also, proportion of skilled workers and both premiums are calculated using the NSSO dataset for looking at any sort of discrepancies in the proposed model.

It can be seen from Table 6 that for agriculture, forestry and fishing there is a marginal increase in capitallabour ratio over the two reference periods but the growth rate is very high and the same increase can be noticed in premium-wise share of skilled workers for premium 1 from 1.81 to 1.82 , however, for premium 2 the share of skilled workers witnesses a fall in growth rate from 1.21 to 1.12. For Mining and Quarrying K/L ratio declines in the second period from 0.86 to -2.71 and both the premiumwise skilled labour shares show a rise in both the reference periods.

Interesting results can be seen in case of manufacturing sector where the capital skill complementarity is argued to be present by various authors $\frac{9,10}{}$. There is a decline in capital-labour ratio witnessed over the second reference period and on the contrary, there is a rise in value of skilled workers employed in premium 1 and almost stagnant in premium 2. Even though there is a rise in share of skilled workers hired in manufacturing sector under premium 1 approach but there is deceleration in K/L ratio as that is showing a fall.

The $\mathrm{K} / \mathrm{L}$ ratio increased faster in the second period for electricity, gas, water and construction but for premium 1 wise share of skilled workers for both the reference points witnessed a fall. Further, there is a rise in the share of skilled workers for premium 2 in Electricity, Gas and Water and fall in construction in the second period where the growth rate is actually negative.

The $\mathrm{K} / \mathrm{L}$ ratio growth is negative in first period and increasing in the second period for trade, hotels and restaurants and skilled worker share for both premiums also increase over the two periods. For transport, storage and communication capital-labour ratio increased and so did the share of skilled workers for both the premiums. In finance, insurance and real estate there is rise in $\mathrm{K} / \mathrm{L}$ ratio and fall in share of skilled workers in premium 2 and marginal improvement for premium 1 but the percentage share is negative in both the periods for premium1. Overall, for all sectors there is deceleration in growth rate for $\mathrm{K} / \mathrm{L}$ ratio over the two reference periods and on the contrary there is rise in share of skilled workers for premium 1 and stagnancy in growth rate for premium 2 .

It can be observed that the changes in the K/L ratio are moving in different directions as compared to share of skilled workers. Although capital-labour ratio is rising for many sectors but that has not resulted in a rise in demand of skilled workers or rise in the share of skilled workers as can be seen for manufacturing sector. The movement among the two variables i.e. capital labour ratio and employment of skilled workers don't show much relation. Even in proportionate terms of aforementioned variables don't show complementary relation, when rising in the same direction then too proportion of rise is substantially different.

So, it can safely be said that movements/change in share of skilled workers in the Indian Economy are not caused by skill-complementary technologies being employed. Even after high supply of skilled workers, the technological advancements are not converting into employment opportunities for the skilled workers in India. It can also be observed that the belief that technological changes will be intrinsically skill complementary, is not a universal fact that may hold for all countries. Whether the technological change is skill-complementary or is skill replacing, it depends on profitability of the change. Historical relations among technology reflect that major changes in the technique of production are undertaken due to the entrepreneurs' motive to reap more profits rather than due to any exogenous change. During the historical study of production process the technological changes have not always been skill complementary. When production change took place from artisanal to factories (1830's to 1880 's) the change was skill displacing as more skilled workers were replaced by rather less skilled or unskilled workers. Then shift from factories to assembly line production (1900's) medium skilled labourers were replaced by unskilled labourers. Only after the computer revolution in 1960's most of the technological changes are capital complementary but that is not true for all countries. Capital-skill complementarity can therefore 
safely be negated, as these are not observed in almost all sectors of the economy.

\section{Sectoral Share and Skill Premium}

Table 7 shows sectoral share of employment and Industry-wise growth of employment across different sectors during 1983-2011. For agriculture the sectoral share has been consistently declining and the decline has been steeper in the last reference period i.e. from 2004 to 2011 where decline is almost by 10 percent. Industry wise growth of employment is also negative during this period which shows a tremendous shift in economy from agriculture products to the other sectors of the economy. Fall in the proportion of workers employed in agriculture is absorbed in unorganized segments of manufacturing, construction and other services of the economy which don't require high degree of skill. The rise in the share of employment in the last reference period is highest for construction sector which is largely dominated by unskilled labourers. Displaced agricultural labourers with least set of skills seem to have been absorbed in the construction sector. Even in the initial part of analysis it is already observed that in construction sector proportion of skilled workers has not gone up drastically, and wherever it has increased, it is not able to overshadow the relative rise of unskilled workers that have entered the construction sector from agriculture. Here the relation between movements of skill premium can be related with the overall movement of employment in the economy. The movement of skill premium is very much in tandem with shifts in the sectoral shares of employment in the economy. When workers move within sector then that movement is because of skill Premium but when the workers move between sectors i.e. for example from agriculture to industry then that movement happens because of relative absorption capacity of sectors.

Workforce in India has moved from agriculture sector to secondary sector but the growth of secondary sector has been stagnant for the past three decades. For tertiary sector there is constant increase in share of contribution to GDP but growth in tertiary sector is productivity led and not employment led. So even after constant rise in GDP growth for India, driven primarily by the tertiary sector, there is not much rise in employment share of workforce working in tertiary sector.

\section{Broad Findings}

Summarising our broad findings, we can say that no concrete evidence of the presence of SBTC and capital-skill complementarity could be observed in the Indian labour market. There were sectors where capital-labour ratio was increasing and percentage share of skilled workers in

Table 7. Sectoral Share of Employment (\%) and Industry-wise Growth of Employment (Usual Principal and Subsidiary Status) 1983-2011-12

\begin{tabular}{|c|c|c|c|c|c|c|c|}
\hline & \multicolumn{9}{|c|}{ Sectoral Share of Employment (\%) } & \multicolumn{3}{c|}{ Industry-wise Growth of Employment } \\
\hline Sector/Industry & $\mathbf{1 9 8 3}$ & $\mathbf{1 9 9 3 - 9 4}$ & $\mathbf{2 0 0 4 - 0 5}$ & $\mathbf{2 0 1 1 - 1 2}$ & $\mathbf{1 9 8 3 / 1 9 9 3 - 9 4}$ & $\mathbf{1 9 9 3 - 9 4 / 2 0 0 4 - 0 5}$ & $\mathbf{2 0 0 4 - 0 5 / 2 0 1 1 - 1 2}$ \\
\hline Agriculture & 68.6 & 64.8 & 58.5 & 48.9 & 1.4 & 0.7 & -2 \\
\hline Mining & 0.6 & 0.7 & 0.6 & 0.5 & 3.2 & -0.1 & -0.3 \\
\hline Manufacturing & 10.6 & 10.5 & 11.7 & 12.9 & 2 & 3.2 & 1.5 \\
\hline Electricity & 0.3 & 0.4 & 0.3 & 0.4 & 5.6 & -1.9 & 7.7 \\
\hline Construction & 2.3 & 3.1 & 5.6 & 10.7 & 5.7 & 7.2 & 9.8 \\
\hline Trade & 6.3 & 7.4 & 10.2 & 11.4 & 3.8 & 3.2 & 1.8 \\
\hline Transport & 2.5 & 2.8 & 3.8 & 4.4 & 3.4 & 5.2 & 2.1 \\
\hline Financing & 0.7 & 0.9 & 1.5 & 2.6 & 3.6 & 7.2 & 7.8 \\
\hline Community & 8.1 & 9.4 & 7.7 & 8.2 & 3.9 & 0.4 & 1 \\
\hline Total & 100 & 100 & 100 & 100 & 2 & & 1.8 \\
\hline
\end{tabular}

Source: Employment and Unemployment Survey, Various NSS quinquennial rounds. 
those sectors were falling (most notably, agriculture and electricity, gas and water). In construction sector there was tremendous rise in the capital-labour ratio but the share of skilled workers remained stagnant. Observed relations were mostly opposite to the conventional notion of capitalskill complementarity. So, it could be safely concluded that SBTC was not observed in the Indian labour market.

When the presence of skill premium was tested for the Indian Economy, it could be observed that according to methodology of Skill Premium 1 the skill premium was present in a few sectors as was claimed by Roy ${ }^{4}$, Ramaswamy ${ }^{10}$ and Abraham (2007) but when the same analysis was carried out with the help of a more appropriate and better method i.e. skill premium 2 , then the skill premium appeared to be stagnant and there were not much changes observed over the wages drawn by skilled and unskilled workers and the changes were very difficult to observe. Skilled workers (more educated work force) were not able to increase their wages at a great pace. There is a large reserve army of labour in both skilled and unskilled category of workers and due to this there is no incentive to gain education for the population which in turn leads to large sections of population being unskilled and less educated. The argument given by firms for large scale unemployment is the deteriorating level of skills of Indian labour force and this vicious circle continues to plague the Indian labour force. Indian labour force is growing in size but the jobs for the same are not being created. If this is interpreted in demand-supply context, then skill premium cannot be explained due to demand supply factors but large scale unemployment can be easily be explained. Skill premium movements could be determined by absorptive capacity of movement of labourers between sectors as seen in agriculture and manufacturing.

\subsection{Beyond Technology and Demand Supply} Framework for Skill Premium

Majority of technological changes and complementary skill requirements across the globe and also in India are driven by profit motive and changing relative price of inputs. New technological advancements are encouraged by producers only when it leads to relative reduction in costs. So, if there happens to be a rise in relative supply of skilled workforce, but production with a new technology and skilled labour, does not reduce costs, then the new technology would not be adopted.
Even during the industrial revolution, as argued by Goos ${ }^{3}$, home production was more efficient but factory mode of production was adopted as it reaped more profits for factory owners rather than for the whole society. Capital skill-technology complementarity is difficult to be explained in Walrasian notions of equilibrium as these are determined by twin forces of demand and supply.

New and improved technologies are adopted in labour process only when more labour power can be extracted from labour rather than the conventional notion which is that the skill complimentary technologies will be adopted. If the capitalist finds other methods to extract higher labour power from workers, then new technology would not be adopted. Few of the methods of extraction of more labour power are large scale flexibility, outsourcing, formal-informal organisation nexus, hire and fire policy and relaxation of labour laws. All these methods help in extraction of more labour power, relative to technology and skill advancement, and seem to be a better alternative for capitalist to increase profit ${ }^{27,29}$. Presence of skill premium is already in question and through above argument it can be established that technological changes do not happen due to demand and supply of skilled workforce. Now for the above argument to work, there is a need for unlimited supply of labour force and presence of involuntary unemployment as well as they would help in acting as balancing force over the demand driven forces to not affect the levels of profits. If there is not enough labour interested to work at the given wage rate then the capitalist would have to look for other methods to increase profits but in a country like India, where there is unlimited supply of labour and large involuntary unemployment, the argument works perfectly.

Larger reserve army of labour and large scale involuntary unemployment dampens the price effect and market size effect. Price effect, where goods using scarce factor will have more and more innovations and rise in technology, but when there is large reserve army of unskilled labour, even after rise of share of skilled labour, the changes in effect of price will be negligible due to relative composition of labourers.

In case of market size effect, where large scale innovation is directed to abundant factor which in turn is used by large section of population. When in a country like India, where even if there is a rise in the share of skilled workers, even in absolute terms, the rise is very small as compared to the share of unskilled workers. From Table 2 it could be seen that 68 percent of workforce of 
India is less than $8^{\text {th }}$ pass which means largely unskilled so effect of skilled labour force relatively very less compared to unskilled labour force of India. So rise in skilled workers would not be able to induce skill-complementary technology and in turn result in rise in skill premium. So even if there is rise in skill complementary technology but that rise would never be high enough or more than the growth rate of skilled workforce. This demand-supply mismatch makes evidence of skill premium in current Indian situation, almost impossible to be observed.

Looking at specific Skill Development and Vocational Education programmes in India would not help in solving the skilling problem on account of many reasons such as only 4 percent of Indian workforce is part of any formal vocational training, 3 months and 6 months' courses cannot make a person skilled, lack of quality teachers available and lack of involvement of private sector in financing these programmes ${ }^{\underline{6}}$.

There has been low placement in both Pradhan Mantri Kaushal Vikas Yojana (PMKVY) and Standard Training Assessment and Reward a (STAR) schemes. (STAR scheme was operational between August 2013 and September 2014, later it was replaced by PMKVY). Only 13.2 percent got placement out of 18.03 lakhs trained under PMKVY in the year 2015-16 and under STAR scheme only 8.5 percent of the total 14.15 lakhs persons trained, got placement. This is accompanied by large discrepancies in distribution of monetary benefits by the the local institutions $\frac{11,34}{}$. PMKVY was given additional 1500 crores for the year 2017 without providing for the target report for the year 2016 and data show that the scheme led to an increase in the number of training institutes which did not transform into producing 'skilled workforce' 11 .

\section{Summing Up and the Road Ahead}

The analysis helps in explaining the observation that the Indian labour market was relatively resistant to global economic crisis but during the periods of high economic growth also labour was not really sensitive or gave any positive results. The argument of jobless growth misses a lot of crucial points. In organised sector there may not be major impact but there is huge level of employment generation in informal sector but wage conditions there are deplorable. Skills are adequately needed to be identified as is reported by India Labour Employment Report (2013) that resources are too heavily concentrated on the training of relatively small groups of highly skilled workers. Problem therefore needs to be re-conceptualized and traditional ways of treating skill problem should be modified drastically. Indian vocational training system is very rigid and very specifically defined. Vocational education system does not offer larger flexibility which restricts the vertical and horizontal mobility and makes it an inferior alternative as compared to the general education.

This analysis on Skill Premium, as well, confirmed that there wasn't much evidence of skill premium found in the Indian economy. Even in sectors where skill premium was present that was due to movement of labour between sectors and; technology has failed to provide any concrete answers for the movement. The demand-supply factors being responsible for movement of wages of skilled workforce have been discussed in relation to the agricultural sector. In fact, even during the Global food crisis when productivity of agriculture was low still there was higher proportion of skilled labourers being employed. This happened as during this period large scale migration from unskilled agricultural sector happened to another unskilled sector i.e. construction. Major reason as argued by different authors behind the same was NREGA ${ }^{12}$. Skill premium showed rise which indicated movement of labourers (unskilled) to other sectors (majorly secondary) and in relative terms it showed rise in wage levels for agriculture sector when it was not the case.

When labour migrated to secondary sectors, there was no wage rise observed in that sector (majorly in manufacturing 1 , manufacturing 2 and construction) as employment levels did show a rise but its effect on wages were not visible. Due to these reasons, the argument of demand supply factors determining movement of skill premium can be negated. Situation in vocational training observed were more deplorable not showing any signs of improvements even under new political regime. Study focussing especially- on manufacturing sector showed the rising gap between wages and profits and cited reasons for this rising gaps as flexibilisation, outsourcing, deunionisation, and contract workers, which help a capitalist increase his profits without improving skills of workers that may in turn lead to rise in productivity ${ }^{24,28}$.

So, whether employability and wages actually result from attaining skills and education, is a matter of contention. Two contradictory arguments run in our country that there is shortage of skilled workforce in the economy and also there is highest level of unemployment in India in Graduate level youth which is around 12 percent ${ }^{32}$. One of the possible reasons behind the same is quality of skill training imparted in India at both general 
and vocational level. The argument of increasing the supply of skilled and educated workforce will transform into creation of more jobs, is an attempt to correct macro-policy distortions through micro interventions. This has not proved successful in the past and current results are also very depressing. This only results in overcrowding and further reduction in wages of unskilled workers. So, eventually the economy is left with large pools of unemployed skilled workforce and a large pool of unskilled workers working at bare minimum wage necessary for survival (sometimes even less than that).

Production process and changes can very well be summed up in words of Braverman ${ }^{13}$ : "When skill-biased techniques are profitable, only then firms will have incentives to develop and adopt such techniques". This clearly explains the deskilling of jobs that took place in $19^{\text {th }}$ century as at that time deskilling technology was profitable because it helped replacing the scarce and expensive factors the skilled artisans -by relatively cheap and abundant factors -unskilled manual labour force of men, women, and children. Changes in the relative supply of skilled and unskilled workers explain both the presence of skillreplacing technical change in the nineteenth century and skill-biased technical change during the twentieth century.

It is believed that capitalist exploitation distinguishes itself from previous exploitative structures by setting up norms of contract. Contractual employment reduces the bargaining power of worker and even after attaining high levels of skills the adequate wages for the same are not paid. One of the most ridiculous arguments presented regarding the flexibility debate in India, is that in order to create more employment, capital and increasing the GDP and development, capitalists should enjoy the privilege to throw people out of jobs. Flexibility of labour appears to be an ideological construct which has received backing of the capitalists regarding the way in which the workers can be made more disposable.

One of the problems already put forward while discussion of sources of data, was lack of adequate data pertaining to skills is available for labour force. The data is dependent on educational qualifications and the major reason held for that is inefficient skill development system ${ }^{26}$. Even the data collected by NSDC in 2014 regarding future forecast of skill requirements received critique from various authors due to its weak methodology and the data is again being collected. Out-dated data is available for the number of skilled persons in the official database which shows the low importance given to skills by our government. Skill specification and measurability should be treated as a foremost issue for development of an efficient labour force. Skill India programme has put forward skill as a major policy issue but the system is supply driven where private sector is not involved in training at a large scale because of which demand side constraint is faced in Skill Development System of India.

In the Indian case, the demand for skills in any part of the economy will be determined by relative absorption capacity of different sectors rather than getting affected by relative skill requirement or skill demanded. So demand supply factors do not affect the movement of skilled workers and in turn skill premium for the workers. As we saw in the above analysis that large share of labourer shifted from agriculture and was absorbed by informal sectors of construction and manufacturing sectors. This was because there is relative demand for unskilled workers in these sectors. There is no incentive among capitalists to provide skills to the workers as they have other means available to increase their profits. Absorption capacity in a country like India is always high in sectors that require less skill as we have a large pool of unskilled labourers. One of the recommendations of the study is to increase vocational education in India at the school level.

Technology may change skill premium in case of the Indian economy only in case there is full employment but that situation is practically impossible due to the large reservoir of labour. In the long-run there are fewer possibilities for endogenous technological change growth in skill-complementary technology outpacing the rising supply of skilled workers. Blind application of developed country technologies is not appropriate for a country like India, due to large scale unemployment both amongst the educated and less educated workforce.

Virtuous circle of rise in skill Premium as suggested by Acemoglu ${ }^{14}$ is not possible in case of a country like India due to inefficient education system combined with lack lustre skill development policies which do not cater to demands of the production market and do not provide any sort of up-scaling of skills which can trigger the rise of skill premium.

\section{References}

1. Srivastava R. Education, skills and the emerging labour market in India. The Indian Journal of Labour Economics. 2000; 51(4).

2. NSSO. NSS 69th. Round (Jul 2011-Jun 2012); No.515 $(69 / 10 / 1)$ employment and unemployment situation in India, Part-II; 2014. 
3. Goos M. How world of work is changing. International Labour Office, Bureau for Employers' Activities, Geneva: ILO; 2013.

4. Roy S. Skill premium: What caused the 'mismatch'? MPRA Paper 18010, University Library of Munich, Germany; 2008.

5. Asuyama Y. Skill sorting, inter industry skill wage premium: evidence from India. Institute of Developing Economics, IDE discussion paper no : 278; 2011.

6. Mehrotra SK. Indias skills challenge: reforming vocational education and training to harness the demographic dividend. New Delhi: Oxford University Press; 2014. https:// doi.org/10.1093/acprof:oso/9780199452774.001.0001

7. IMA The India Employment Report. Powerpoint Presentation [Internet]. 2017. Available from: http:// www.ima-india.com/pdfs/the-india-employment-reportsample-slides.pdf.

8. Unni J, Rani U. Flexibility of labour in globalising India: The challenge of skills and technology. NewDelhi: Tulika Books; 2008.

9. Banga R. Liberalization and wage inequality in India. Working paper no. 156, Indian council for research on international economic relations; 2005.

10. Ramaswamy KV. Wage inequality in Indian manufacturing: Is it trade, technology or labour regulations? Indira Gandhi Institute of Development [Internet]. 2008. Available from: http://www.igidr.ac.in/pdf/publication/WP-2008-021.pdf.

11. MSDE. Report of the Committee for Rationalization and Optimization of the Functioning of the Sector Skill Councils. Volume 1. Ministry Of Skill Development And Entrepreneurship, Government Of India, New Delhi; 2016.

12. Roy S. Changing factor incomes in industries and occupations, Institute for Studies in Industrial Development. Working paper no: 262; 2012.

13. Braverman H. Labour and monopoly capital: The degradation of work in the thirteenth century. New York: Monthly Review Press; 1974. PMCid:PMC301631

14. Acemoglu D. Technical change, inequality and the labour market. Journal of economic literature. 2002; 40(1):7-72. https://doi.org/10.1257/jel.40.1.7

15. ILER. Indian labour employment report: Workers in the era of globalization. Institute for human development, Academic Foundation, Delhi; 2014.

16. Abraham V. The effect of information technology on wage inequality: Evidence from Indian manufacturing sector. Centre for Development Studies; 2010.

17. AICTE. Annual Report 2011-12. All India Council For Technical Education, 7th Floor, Chanderlok Building, Janpath, New Delhi - 110001 [Internet]. 2012. Available from: https:// www.aicte-india.org/downloads/annual_report_11_12.pdf.

18. ASI. Time series data on Annual survey of industries, Government Of India Ministry of Statistics And Programme Implementation Central Statistics Office (Industrial Statistics Wing) Kolkata; 2013.
19. Autor D, Katz L. Computing inequality: Having computers changed the labour market? Quarterly journal of labour economics. 1998; 113(4):1169-213.

20. Berman E, Somnathan R, Tan HW. Is skill biased technological change here yet? Evidence here yet? Evidence from Indian Manufacturing in the 1990's, The World Bank, World Bank Policy Research Working Paper 3761; 2005.

21. CSO. 'National accounts statistics', Central Statistics office, National accounts statistics, Back Series 1950-51 to 19992000; 2007.

22. Das K, Kalita G. The employment potential of labour intensive industries in India's manufacturing. Indian council for research on international economic relations, Woking paper no -236; 2009.

23. Government of India. Education, skill development and labour force. Ministry of Labour and Employment, Chandigarh; 2014.

24. Marx K. Das Kapital. Delhi: Jainco Publishers; 1867.

25. Mehtabul A. India's increasing skill premium: Role of demand and supply. Southern Methodist University and IZA Discussion Paper No. 3968; 2009.

26. NSSO. Status of vocational training in India, 66th Round Survey Report. New Delhi; 2013.

27. Rosenber N. Perspectives on technology. New York: Cambridge University Press; 1976. https://doi.org/10.1017/ CBO9780511561313

28. Roy S. Labour reforms: a marxian relook. Vikalp [Internet]. 2013. Available from: http://www.vikalp.ind.in/2015/02/ labour-reforms-marxian-relook.html

29. Smith A. An inquiry into the nature and causes of the wealth of nations. New York: Bantam Dell, Random House INC; 1776. https://doi.org/10.1093/oseo/instance.00043218

30. AISHE. All India Survey Of Higher Edication 2012-13. Government of India, Ministry of Human Resource and Development, Department of Higher Education, New Delhi. 2012

31. Milner C. Trade, Technology and Wage Inequality In Developing Countries: Evidence From Indian Manufacturing. Nber Working Paper 5823, Nber. 2005

32. Singh CSK, 'A Dissenting Essay Skill, Education and Employment, Economic and Political Weekly, 2003; 38(31).

33. Azam M. 'India's Increasing Skill Premium: Role Of Demand And Supply', Iza Discussion Paper No. 3968. 2008.

34. Srivas R. The Macroeconomic Loss due to Violence Against Women: The Case of Vietnam, Feminist Economics. 2017; 23:4: 62-89.

\section{Notes:}

a STAR scheme was operational between August 2013 and September 2014, later it was replaced by PMKVY. 